\title{
ВОЛЬТАМПЕРОМЕТРИЧЕСКОЕ ОПРЕДЕЛЕНИЕ БЕТУЛИНА В БИОЛОГИЧЕСКОЙ АКТИВНОЙ ДОБАВКЕ
}

Нурпейис Е., Слепченко Г.Б.

Национальный исследовательский Томский политехнический университет, Томск, Россия enlik.nurpeiis.94@mail.ru

DOI: 10.26902/ASFE-11_124

Пентациклические тритерпеноиды представляют собой набор из более чем 4000 встречающихся в природе соединений [1]. Одним из главных представителей этого класса является бетулин. В литературных данных описаны более 15 полезных свойств бетулина, комплексно воздействующих на все системы организма [2]. Идентификацию природных соединений проводят с помощью физико-химических методов анализа. К таким методам относятся высокоэффективная жидкостная хроматография (ВЭЖХ), газовая хроматография (ГФ), и многие другие [3]. Хотя эти методы удовлетворяют условиям точности, специфичности и воспроизводимости, однако, они все еще отнимают много времени и требует сложного оборудования. В настоящее время широкое применение получили электрохимические методы определения, в частности, инверсионная вольтамперометрия.

Цель работы заключалась в исследовании условий вольтамперометрического определения бетулина на золото-углеродном электроде и разработка алгоритма методики анализа биологической активной добавки (БАД) на содержание бетулина методом вольтамперометрии. Регистрацию аналитического сигнала бетулина проводили на комплексе CТА. Сущность методики измерения состоит в переводе бетулина из БАДа в раствор путем растворения навески пробы в этаноле: хлороформе (3:1) с последующим вольтамперометрическим (BA) определением массовой концентрации бетулина. Получение аналитического сигнала бетулина основано на способности бетулина окисляться на модифицированном стеклоуглеродном электроде в растворе фонового электролита, 0,1 M перхлорате натрия, растворенный в ацетонитриле и спирте $(1: 1)$, при потенциале накопления равном -1,000В. По методу добавок оценена массовая концентрация бетулина в препарате «бетулин высокой степени очистки 99,9\%» и получена удовлетворительная сходимость результатов с рецептурным значением. Выполненные исследования расширяют возможности использования вольтамперометрического метода для количественного определения бетулина в лекарственных препаратах.

Предложен алгоритм вольтамперометрической методики анализа БАД на содержание бетулина и проведена оценка правильности полученных результатов методом «введенонайдено». Получены удовлетворительные результаты, погрешность измерения не превышала $18 \%$.

\section{Список литературь}

1. Connolly J.D., Hill R.A., Dey P. M., Harborne J. B. In Methods in Plant Biochemistry, Academic Press: San Diego, CA, 1991. Vol. 7. Chapter 9. P. 331-359.

2. Толстиков Г.А., Флехтер О.Б., Шульц Э.Э., Балтина Л.А., Толстиков А.Г. Бетулин и его производные. Химия и биологическая активность // Химия в интересах устойчивого развития. 2005. Т.13. С.1-30.

3. Zhao G., W. Yan., D. Cao. Journal of Pharmaceutical and Biomedical Analysis, 2007. Vol. 43. P. 959-962. 